\title{
Reografia
}

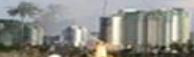

Malavsian Iournal of Society and Space

\section{Dilema masalah jenayah pecah rumah impak pembangunan Lebuhraya Baru Pantai (NPE)}

\author{
Marzilla $\mathrm{M}^{1}$, Rosniza Aznie $\mathrm{CR}^{1,2}$, Zaini $\mathrm{S}^{1,2}$ \\ ${ }^{1}$ Program Pengurusan Persekitaran, Fakulti Sains Sosial dan Kemanusiaan, \\ Universiti Kebangsaan Malaysia \\ ${ }^{2}$ Program Geografi, Pusat Pembangunan, Sosial dan Persekitaran, \\ Fakulti Sains Sosial dan Kemanusiaan, Universiti Kebangsaan \\ Malaysia \\ Correspondence: Marzilla Muhammad (email: marzilla_2302@yahoo.com)
}

Received: 28 June 2019; Accepted: 11 November 2019; Published: 25 November 2019

\begin{abstract}
Abstrak
Pecah rumah merupakan salah satu masalah sosial yang dihadapi oleh penghuni di Seksyen Petaling Jaya Selatan 2 (Seksyen PJS 2) impak daripada pembinaan Lebuhraya Baru Pantai (NPE) setelah ia beroperasi. Artikel ini bertujuan untuk membincangkan dilema yang dialami oleh penghuni di Seksyen PJS 2 terhadap masalah jenayah pecah rumah setelah Lebuhraya NPE beroperasi. Kajian ini menggunakan 357 set borang soal selidik yang diwakili oleh ketua isi rumah di Seksyen PJS 2. Data yang diperolehi dianalisis untuk mendapatkan nilai kekerapan, peratusan dan ujian chi-kuasa dua.Pada peringkat awal pengoperasian Lebuhraya NPE, trend jenayah pecah rumah di Seksyen PJS 2 dari tahun 2005 sehingga tahun 2006 menunjukkan peningkatan sebanyak 46 kes jenayah pecah rumah. Trend jenayah pecah rumah di kawasan perumahan ini beberapa tahun kebelakangan ini dari tahun 2013 sehingga tahun 2017 menunjukkan penurunan sebanyak 88 kes. Namun, hasil kajian mendapati penghuninya masih berasa bimbang dan tidak selamat mengenai aspek keselamatan kediaman dan hartabenda mereka. Kajian ini mengenal pasti faktor yang mendorong perlakuan jenayah di Seksyen PJS 2 seperti kemudahan akses jalan raya perumahan dan Lebuhraya NPE, kepadatan penduduk, masalah sosial, kawalan keselamatan dan kecanggihan sains dan teknologi. Penemuan kajian ini diharapkan dapat meningkatkan kesedaran kepada penduduk tempatan dan Pihak Berkuasa Tempatan mengenai keseriusan masalah pecah rumah yang berlaku supaya langkah pencegahannya dapat diambil dengan mengambil kira faktor risiko dan potensi jenayah secara menyeluruh untuk kawasan kediaman ini bebas jenayah.
\end{abstract}

Katakunci: jenayah, kawasan perumahan, keselamatan, lebuh raya, pembangunan, penghuni 


\title{
The dilemma of housebreaking crime impact from the development of the New Pantai Expressway (NPE)
}

\begin{abstract}
Housebreaking is one of the social problem that have been facing by residents at Seksyen Petaling Jaya Selatan 2 (Seksyen PJS 2) in impact of construction of New Pantai Expressway (NPE) following its operation. This article aims to discuss the dilemma experienced by residents in Seksyen PJS 2 on the problem of housebreaking crime following its operation NPE Highway. This study used a 357 set questionnaire form represented by the head of households in Seksyen PJS 2. The data obtained were analyzed for frequency, percentage and chi-squared test values.The early stages of operation of the NPE Highway, the trend of housebreaking crime in Seksyen PJS 2 from 2005 to 2006 showed an increase of 49 housebreaking crime cases. The trend of housebreaking crime in the housing area in recent years from 2013 to 2017 showed a decline of 88 cases.However, the study found that residents are still worried and unsafe about aspects of home security and their property.This study identify factors driving crime behavior in Seksyen PJS 2 like accessibility of in the housing route and NPE Highway, population density, social problems, security and sophistication of science and technology.The findings of this study are expected to raise awareness among locals and the Local Authorities about the seriousness of the housebreaking problem so that preventative measures can be taken into account crime risks and potentials as a whole for this residential area a crime-free.
\end{abstract}

Keywords: crime, development, highway, housing area, residents, security

\section{Pengenalan}

Lebuh raya di kawasan bandar banyak dibina berdekatan dengan kawasan perumahan sedia ada disebabkan oleh tuntutan pembangunan infrastruktur jalan untuk menampung peningkatan jumlah pengangkutan dan kemudahan aksesibiliti. Namun, kemudahan akses lebuh raya dikaitkan dengan masalah jenayah. Kemudahan akses lebuh raya adalah salah satu faktor yang mempengaruhi peningkatan permasalahan jenayah. Kawasan perumahan berdekatan dengan laluan lebuh raya berisiko untuk menjadi sasaran penjenayah disebabkan oleh kemudahan akses yang disediakan oleh lebuh raya tersebut telah memudahkan pergerakan penjenayah untuk memerhati keadaan sekeliling kawasan kediaman tersebut dan melarikan diri (Fink, 1969). Selain daripada faktor akses, kawalan keselamatan, kepadatan penduduk, masalah sosial dan kecanggihan sains dan teknologi merupakan antara faktor yang boleh mendorong dan mendesak seseorang untuk melakukan aktiviti jenayah di kawasan tersebut (Yuen, 2004; Sidhu, 2005).

Kawasan perumahan Seksyen Petaling Jaya Selatan 2 (PJS 2) juga tidak terkecuali daripada terdedah kepada masalah pecah rumah disebabkan oleh pembinaan Lebuhraya Baru Pantai (NPE). Pada tahun 2016, terdapat sebanyak 728 kes jenayah hartabenda di Seksyen PJS 2 berbanding 240 kes jenayah kekerasan (PDRM, 2017). Data tersebut menunjukkan jenayah hartabenda di kawasan Seksyen PJS 2 melebihi jenayah kekerasan. Masalah jenayah hartabenda khususnya jenayah pecah rumah di sesebuah kawasan perumahan akan menghasilkan persekitaran yang tidak selamat dan menimbulkan rasa takut serta kebimbangan kepada penghuninya mengenai aspek keselamatan awam khususnya kediaman 
dan hartabenda. Secara tidak langsung, masalah pecah rumah tersebut boleh menjejaskan kualiti hidup penduduk setempat.

Oleh demikian, artikel ini bertujuan untuk membincangkan dilema yang dialami oleh penghuni di Seksyen PJS 2 terhadap masalah jenayah pecah rumah setelah Lebuhraya NPE beroperasi. Penemuan kajian ini diharapkan dapat meningkatkan kesedaran kepada penduduk tempatan dan Pihak Berkuasa Tempatan mengenai keseriusan masalah jenayah pecah rumah yang berlaku agar tindakan pencegahan jenayah pecah rumah dapat diambil dengan mengambilkira faktor risiko dan potensi jenayah secara menyeluruh supaya kawasan ini menjadi perumahan bebas jenayah.

\section{Kajian literatur}

Jenayah didefinisikan sebagai sebarang perbuatan atau kesalahan yang membahayakan masyarakat dan boleh disabitkan kesalahannya di sisi undang-undang seperti hukuman denda atau penjara (Aslie, 1990). Jenayah ialah kesalahan yang dilakukan oleh seseorang dengan niat hendak melakukan kesalahan itu, maka dengan sebab kesalahan itu orang yang bertanggungjawab boleh dihukum dengan balasan setimpal kerana melakukan perkaraperkara yang salah disisi undang-undang. Dengan erti kata, jenayah ialah apa-apa yang boleh memberikan masalah atau kesusahan kepada orang lain.

Jenayah indeks terbahagi kepada dua jenis iaitu jenayah kekerasan dan jenayah hartabenda. Jenayah kekerasan seperti bunuh, rogol, samun berkawan bersenjata api, samun berkawan tanpa bersenjata api, samun bersenjata, samun tanpa bersenjata dan mencederakan (PDRM, 2017). Sementara, jenayah hartabenda seperti curi, ragut dan pecah rumah. Dalam Kamus Dewan Edisi keempat menyatakan bahawa jenayah pecah rumah merupakan tindakan seseorang sama ada secara individu atau berkumpulan yang memasuki rumah seseorang tanpa kebenaran untuk tujuan rompakan (DBP, 2019).

Pelakuan jenayah adalah antara permasalahan sosial yang melanda kebanyakan bandar di dunia (Kanyo et al., 2015). Berdasarkan teori aktiviti harian, kejadian pecah rumah timbul apabila terdapatnya perhubungan antara wujud peluang dan membolehkan penjenayah bersedia untuk menghadapi situasi tersebut. Menurut Ekblom (1995), ia melibatkan tiga faktor utama iaitu sasaran mangsa, wujud peluang dan motivasi untuk melakukan jenayah. Kewujudan sasaran mangsa yang sesuai ialah rumah yang mempunyai barang-barang berharga seperti kereta mewah. Di samping itu, ketiadaan sesiapa yang boleh bertindak sebagai penghalang untuk memastikan tiada saksi akan melihat kegiatan mereka. Sebagai contohnya, kejadian jenayah berlaku ketika hari bekerja ataupun ketika penghuni pergi membeli belah kerana ia akan mengambil masa untuk penghuni tersebut pulang ke rumah. Tambahan lagi, dengan keadaan persekitaran fizikal dan sosial yang kondusif juga telah menarik perlakuan jenayah bermotivasi untuk melakukan kesalahan itu. Kombinasi ketigatiga faktor ini yang wujud di sesebuah kawasan kediaman memberikan peluang tinggi kepada penjenayah untuk bertindak (Jensen \& Anderson, 2004).

Kajian masalah jenayah pecah rumah di kawasan kediaman telah menarik minat beberapa penyelidik untuk mengkajinya. Antaranya ialah Brearley (1932), Reckless (1933), Schmid (1960a,b), Shannon (1954) dan Harries (1968) mengkaji corak ruang peristiwa jenayah. Sementara ahli ekologi jenayah seperti Burt (1925), Shaw dan McKay (1969), dan Voss \& Petersen (1971), mengkaji corak ruang kediaman jenayah. Wolfgang (1966) mengkaji jenayah pecah rumah di Philadelphia. Beliau berhujah dalam kajiannya iaitu corak ruang kesalahan tidak penting, yang penting hanya kepada pihak polis tempatan. Fink (1969) mengkaji jenayah di kawasan berhampiran dengan lebuh raya. Walaupun perspektif ini saling 
menyokong, teori aktiviti rutin dan corak pola jenayah memberikan penjelasan yang berbeza untuk jenayah yang berlaku di tempat yang berbeza (Eck \& Weisburd, 2015).

Secara umumnya, kemudahan akses menyumbang kepada peningkatan jenayah (Jeffery, 1990; Hennessy \& Pallone, 1992). Menurut Thomas (1976), seseorang penjenayah perlu memiliki kenderaan atau mobiliti untuk memudahkan mereka bergerak dan bertindak ke atas satu perbuatan jenayah, mengikut masa, teknik, sasaran dan tempat yang diinginkan. Lebuh raya memainkan peranan penting iaitu memudahkan pergerakan penggunanya dalam jangka masa lebih singkat dan menyumbang kepada lancar lalu lintas. Namun, kemudahan akses yang disediakan oleh sesebuah lebuh raya boleh menyumbang kepada peningkatan jenayah khususnya jenayah pecah rumah di kawasan sekitarnya.

Laluan lebuh raya berhampiran kawasan perumahan bukan sahaja memudahkan pergerakan keluar masuk penggunanya tetapi juga kepada penjenayah. Lebuh raya memudahkan pergerakan penjenayah dengan menyediakan akses iaitu dari lokasi sasaran mangsa akses ke lebuh raya untuk ke kawasan bandar. Kajian oleh Fink (1969) menunjukkan bahawa kebiasaannya penjenayah melakukan jenayah di kawasan berhampiran dengan lebuh raya arteri utama. Kemudahan laluan keluar masuk di kawasan perumahan dengan laluan lebuh raya memudahkan penjenayah untuk memerhati keadaan sekeliling kawasan kediaman tersebut dan sasaran mangsanya serta memudahkannya untuk melarikan diri. Walau bagaimanapun, ia bergantung kepada jarak antara laluan keluar masuk lebuh raya dan lokasi rumah. Sekiranya, lebuh raya dibina berhampiran dengan lokasi rumah tetapi lorang akses terdekat ke lebuh raya tersebut berada pada jarak yang jauh, maka impak kemudahsampaian dari rumah ke lebuh raya tersebut mungkin terhad dan secara tidak langsung kawasan tersebut kurang berlaku kejadian pecah rumah.

Susun atur fizikal, jenis perumahan dan rupa bentuk kawasan persekitaran merupakan kriteria utama yang menjadi tumpuan perlakuan jenayah (Tabrizi \& Madanipour, 2006). Kawasan perumahan yang mempunyai kemudahan untuk memasuki rumah sabagai sasaran yang sesuai. Penjenayah sentiasa memastikan tiada risiko yang tinggi untuk memasuki rumah tersebut seperti memastikan aktiviti persekitaran yang lemah, kurangnya komunikasi antara komuniti, tiada orang yang sentiasa menggunakan laluan utama, ketiadaan tuan rumah, sistem keselamatan yang dipasang adalah lemah dan ketiadaan polis bertugas di kawasan tersebut. Menurut Thomas (1976), penjenayah mungkin akan meneruskan aktiviti penjenayahan mereka di tempat, masa dan sasaran yang sama tetapi mungkin berbeza dari segi teknik yang akan digunakan seiring dengan kecanggihan sains dan teknologi Revolusi Industri 4.0 pada masa kini. Pelbagai cara dan teknik boleh dipelajari oleh penjenayah dengan mudah dan cepat dengan penggunaan teknologi tersebut.

Masalah pecah rumah memberi impak kepada penduduk tempatan dan ia tidak terbatas kepada aspek fizikal semata-mata tetapi ia meliputi elemen dalaman yang melibatkan aspek psikologi dan emosional seseorang (Aldrin, 1999). Masalah ini telah meningkatkan rasa takut terhadap jenayah di kalangan penduduk yang merasakan bahawa mereka sentiasa berisiko (Nasar \& Jones, 1997). Makna selamat bagi individu mahupun masyarakat sangat penting kerana ia berkait rapat dengan aspek psikologi dan juga kualiti hidup (Zinalibdin \& Lyndon, 2016).

Tumpuan penduduk tempatan terhadap persepsi dan rasa takut terhadap jenayah adalah tidak sama seperti tumpuan oleh pihak polis (Khan, 2015). Pihak polis lebih menfokuskan usaha-usaha terhadap mengurangkan jenayah dan secara faktanya, pihak polis berjaya mengurangkan indeks jenayah dalam tempoh masa tertentu. Manakala, kebimbangan masyarakat tertumpu kepada mesej jenayah yang disampaikan kepada kita menerusi saluran media dan isyarat atau petunjuk yang kita terima daripada ruang atau persekitaran kediaman. Kebimbangan tersebut menjurus kepada rasa takut penghuni terhadap jenayah. Walaupun, indeks jenayah mengalami penurunan sejak beberapa tahun lalu tetapi penghuninya berasa 
kadar jenayah meningkat dan kekal sama, menyebabkan wujud ketakutan terhadap jenayah. Farrall et al., (2007), menyatakan persekitaran bandar yang mempunyai tanda-tanda mencurigai boleh mendatangkan rasa kebimbangan terhadap jenayah. Kajian oleh Cheng \& Smyth (2015) mendapati bahawa kebimbangan terhadap jenayah, kebahagiaan boleh terjejas seperti peluang dikurangkan untuk melibatkan diri dalam aktiviti riadah luar. Masalah ini boleh mempengaruhi status kualiti hidup kerana keselamatan merupakan salah satu indikator dalam Indeks Kualiti Hidup (Kanyo et al., 2015).

Kajian oleh Khan (2015) mendapati bahawa masalah jenayah pecah rumah menyebabkan penduduk tempatan berpendapat bahawa sesebuah kawasan tertentu mungkin merosot dan memberi kesan kepada kualiti hidup. Pemikiran sedemikian menyebabkan penghuni lebih berprihatin untuk memikirkan tentang keselamatan kediaman dan hartabenda terutama ketika mereka tiada di rumah. Oleh demikian, adaptasi terhadap masalah pecah rumah perlu dilakukan oleh penghuni itu sendiri bagi mencegah daripada menjadi mangsa penjenayah. Ekblom (1995) mendefinisikan pencegahan jenayah sebagai mekanisme untuk menimbulkan gangguan kepada perlakuan jenayah.

Blakely \& Synder (1999), mencadangkan empat perkara utama kaedah untuk mencegah jenayah di kawasan perumahan di bandar ialah reka bentuk fizikal, perancangan pengurusan, pihak polis dan interaksi sosial. Keempat-empat perkara tersebut merupakan kaedah Crime Prevention Through Environmental Design (CPTED) untuk mempertingkatkan sistem keselamatan di kawasan kejiranan perumahan. Takrif CPTED diguna pakai oleh National Crime Prevention Institute (NCPI) sebagai satu kaedah reka bentuk persekitaran efektif yang boleh mengurangkan rasa kebimbangan terhadap perlakuan jenayah dan merupakan satu penambahbaikan dalam kualiti hidup (Howard, 1999: Cozens, 2002).

\section{Metod dan kawasan kajian}

Kajian ini menggunakan pendekatan kuantitatif iaitu dengan melibatkan borang soal selidik. Data tersebut hanya akan diambil sekali sahaja sepanjang tempoh kajian ini dan tidak melibatkan tempoh masa yang panjang oleh pengkaji. Seramai 357 orang sampel penghuni Seksyen Petaling Jaya Selatan 2 (PJS 2) yang tinggal berhampiran dengan jajaran Lebuhraya NPE telah dipilih secara rawak mudah untuk dijadikan responden. Dapatan kajian daripada borang soal selidik telah dianalisis dengan menggunakan perisian SPSS versi 22.0 untuk mendapatkan nilai kekerapan, peratusan dan ujian chi-kuasa dua.

Justifikasi pemilihan Seksyen Petaling Jaya Selatan 2 (PJS 2) sebagai kawasan kajian adalah kerana kedudukan lokasinya berdekatan dengan laluan lebuh raya bandar iaitu Lebuhraya Baru Pantai (NPE). Laluan Lebuhraya NPE berdekatan dengan lokasi rumah mendorong kepada perlakuan jenayah kerana ia memudahkan pergerakan mereka keluar masuk ke kawasan sasaran mangsanya. Sebagai contohnya, anggaran jarak minimum antara rumah teres di Jalan Dua dengan jajaran Lebuhraya NPE ialah 16.0 meter. Kawasan Seksyen PJS 2 merangkumi daripada tiga taman perumahan iaitu Taman Dato Harun, Taman Maju Jaya dan Kg. Medan. Panjang jajaran Lebuhraya NPE yang dikaji ialah 1.65 kilometer daripada panjang keseluruhannya19.6 kilometer dengan jarak zon impaknya ialah 900 meter iaitu dari jajaran Lebuhraya NPE ke kawasan perumahan Seksyen PJS 2. Tambahan lagi, tempoh masa lebuh raya ini dibuka kepada lalu lintas iaitu bermula daripada tahun 2004 sehingga sekarang adalah tidak terlalu pendek untuk melihat masalah pecah rumah impak pengoperasian Lebuhraya NPE kepada penduduk tempatan. Disamping itu, kawasan ini juga mempunyai penduduk yang padat dan kawasan paling luas berbanding seksyen Petaling Jaya Selatan lain (iaitu seluas 412.66 ekar) dan diikuti oleh PJS 1 dan PJS 3 (iaitu masing-masing seluas 229.80 ekar) (MBPJ, 2017). 
Seksyen PJS 2 merupakan salah satu kawasan sensitif di sepanjang Lebuhraya NPE yang terdedah kepada masalah jenayah pecah rumah. Seksyen PJS 2 adalah salah satu seksyen di Petaling Jaya Selatan yang termaju dan padat. Petaling Jaya Selatan merupakan salah sebuah mukim yang terletak di dalam negeri Selangor dan dalam pentakbiran Daerah Petaling (Rajah 1). Berdasarkan laporan statistik jenayah daripada Polis Diraja Malaysia (PDRM) bagi tahun 2017, Selangor (408.6) merupakan negeri yang merekodkan jenayah indeks tertinggi selepas Wilayah Persekutuan Kuala Lumpur (716.9). Data ini menunjukkan bahawa penduduk Selangor terdedah kepada masalah jenayah termasuklah Seksyen PJS 2.

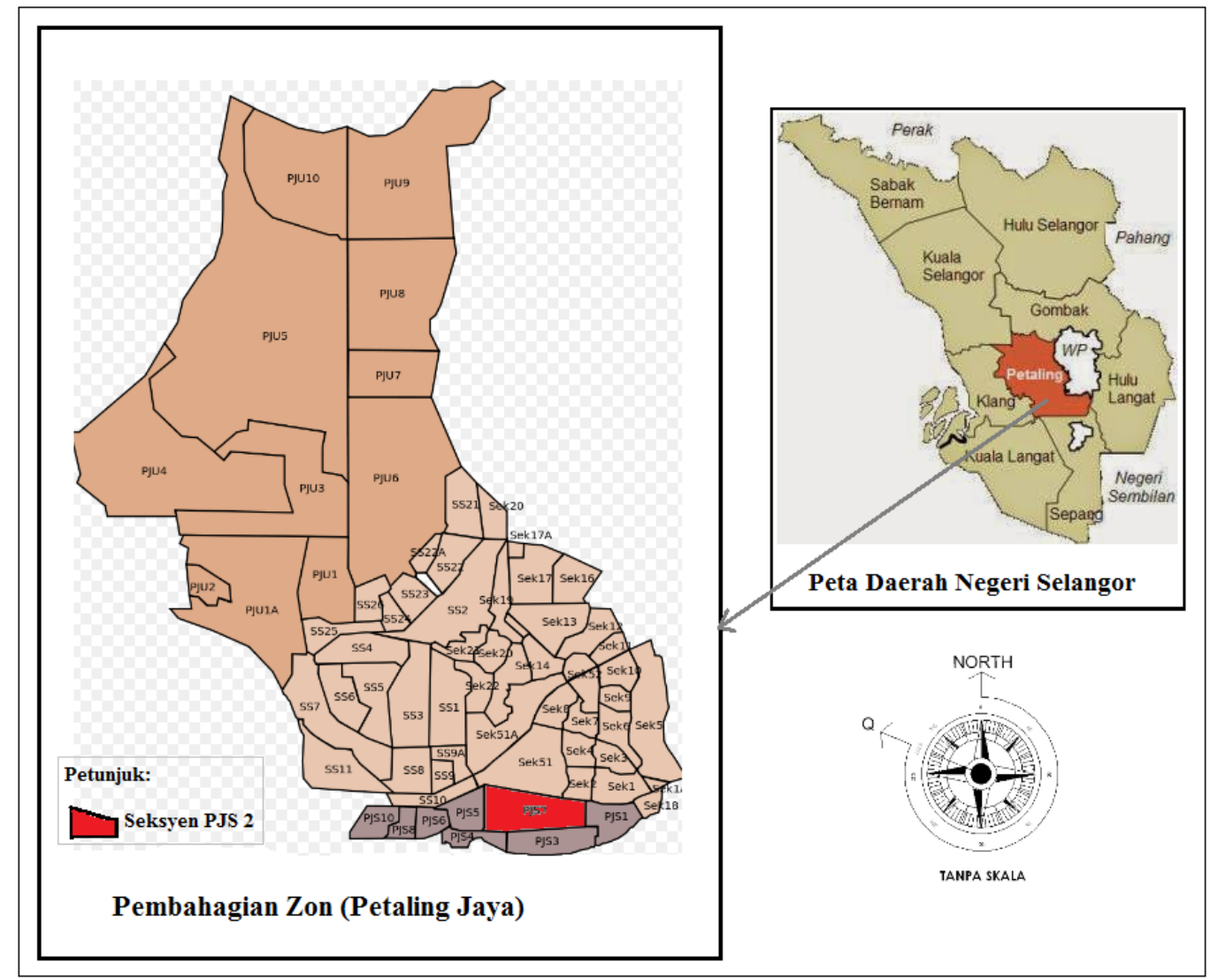

Rajah 1. Peta Seksyen Petaling Jaya Selatan 2 (PJS 2)

\section{Hasil kajian dan perbincangan}

Bahagian ini membincangkan tentang trend jenayah pecah rumah di Seksyen PJS 2 bagi tahun 2005 sehingga tahun 2017 setelah Lebuhraya NPE dibuka kepada lalu lintas kenderaan bermotor. Seterusnya, persepsi penduduk tempatan terhadap faktor yang menajdi pendorong kepada perlakuan jenayah pecah rumah dan diikuti oleh persepsi penduduk tentang masalah pecah rumah dari aspek keselamatan persekitaran kediaman.

\section{Trend jenayah pecah rumah di Seksyen PJS 2}

Jadual 1 menunjukkan trend jenayah pecah rumah di Seksyen PJS 2 bagi tempoh 2005 sehingga 2017 yang diperolehi daripada Ibu Pejabat Polis Diraja Malaysia (PDRM). Pada peringkat awal setelah Lebuhraya NPE beroperasi, trend jenayah pecah rumah di kawasan perumahan Seksyen PJS 2 menunjukkan peningkatan (sebanyak 46 kes) iaitu dari 149 kes bagi tahun 2005 kepada 195 kes bagi tahun 2006 (PDRM, 2017). Peningkatan jenayah pecah rumah di kawasan perumahan Seksyen PJS 2 berlaku disebabkan oleh beberapa faktor yang 
menjadi pendorong perlakuan jenayah salah satunya adalah laluan mudah pergerakan keluar masuk oleh kenderaan bermotor. Masalah ini telah meningkatkan rasa takut terhadap jenayah di kalangan penduduk yang merasakan bahawa mereka sentiasa berisiko.

Jumlah jenayah pecah rumah di kawasan ini bagi tahun 2007 sehingga tahun 2008 masing-masing adalah sebanyak 129 kes. Seterusnya, trend jenayah pecah rumah di kawasan ini dari tahun 2008 sehingga tahun 2009 menunjukkan peningkatan sebanyak 26 kes pecah rumah. Manakala, jumlah jenayah pecah rumah dari tahun 2009 sehingga tahun 2010 menunjukkan trend penurunan sebanyak 42 kes. Kemudian, trend jenayah pecah rumah di kawasan ini menunjukkan sedikit peningkatan iaitu sebanyak 3 kes dari tahun 2010 kepada tahun 2011. Peningkatan trend jenayah pecah rumah di Seksyen PJS 2 adalah dipengaruhi oleh pelbagai faktor. Pada tahun berikutnya iaitu dari tahun 2011 kepada tahun 2012, trend jenayah pecah rumah di kawasan perumahan ini menunjukkan penurunan sebanyak 42 kes.

Seterusnya, trend jenayah pecah rumah di kawasan perumahan Seksyen PJS 2 dari tahun 2013 sehingga tahun 2017 menunjukkan penurunan sebanyak 88 kes pecah rumah iaitu daripada 155 kes kepada 67 kes pecah rumah. Usaha komited yang dilakukan oleh pihak kerajaan dan penduduk tempatan dalam usaha membanteras jenayah di Seksyen PJS 2 telah berjaya mengurangkan jumlah jenayah pecah rumah di kawasan ini. Walaupun, kadar jenayah pecah rumah di kawasan perumahan ini mencatatkan penurunan tetapi ia belum tentu berjaya mengurangkan kebimbangan dan ketakutan terhadap jenayah yang dialami oleh penghuni di kawasan ini mungkin disebabkan oleh penghuni berasa kadar jenayah meningkat dan kekal sama.

Jadual 1. Trend jenayah pecah rumah di Seksyen PJS 2 bagi tempoh 2005-2017

\begin{tabular}{cc}
\hline Tahun & Bilangan kes jenayah \\
\hline 2005 & 149 \\
2006 & 195 \\
2007 & 129 \\
2008 & 129 \\
2009 & 155 \\
2010 & 113 \\
2011 & 116 \\
2012 & 74 \\
2013 & 155 \\
2014 & 136 \\
2015 & 104 \\
2016 & 97 \\
2017 & 67 \\
\hline
\end{tabular}

Sumber: Ibu Pejabat Polis Diraja Malaysia (PDRM) 2017

\section{Pengetahuan penduduk terhadap faktor mendorong perlakuan jenayah pecah rumah}

Jadual 2 menunjukkan pengetahuan responden mengenai faktor yang mendorong kepada perlakuan jenayah pecah rumah di kawasan perumahan Seksyen PJS 2 setelah Lebuhraya Baru Pantai (NPE) dibuka kepada lalu lintas. Soalan soal selidik bagi bahagian ini adalah melibatkan pilihan jawapan YA, TIDAK dan TIDAK PASTI. Berdasarkan jadual tersebut, kemudahan akses daripada jalan perumahan Seksyen PJS 2 merupakan faktor tertinggi yang mendorong kepada perlakuan jenayah pecah rumah dengan mencatatkan sebanyak 91.0 peratus responden yang menanda YA. Keadaan jalan raya di kawasan perumahan ini jenis 
jalan dua lorong dua hala dan tiada halangan atau sekatan jalan untuk pergerakan keluar masuk kenderaan bermotor ke kawasan perumahan mereka.

Masalah sosial adalah faktor kedua yang mendorong kepada perlakuan jenayah dengan mencatatkan sebanyak 89.1 peratus responden yang menanda YA. Masalah sosial seperti vandalisma, mabuk, penyalahgunaan dadah, ragut dan sebagainya. Masalah ini menyebabkan penduduknya berada dalam keadaan bimbang dan gelisah mengenai aspek keselamatan awam dengan alasan masalah sosial boleh mendorong kepada perlakuan jenayah. Seterusnya, terdapat sebanyak 88.0 peratus responden menyatakan YA kemudahan akses daripada Lebuhraya NPE merupakan faktor ketiga tertinggi yang mendorong kepada perlakuan jenayah. Kemudahan laluan keluar masuk antara kawasan perumahan ini dengan Lebuhraya NPE telah memudahkan pergerakan penggunanya dan sekali gus, menggalakkan perlakuan jenayah. Sebagai contoh, lokasi rumah yang dekat dengan laluan keluar masuk Lebuhraya NPE telah memudahkan penjenayah untuk melarikan diri apabila terasa terancam atau setelah siap melakukan aktiviti pecah rumah. Jelas menunjukkan bahawa keadaan jarak yang dekat antara lokasi rumah dengan laluan Lebuhraya NPE telah memudahkan pergerakan keluar masuk penjenayah.

Faktor keempat yang mendorong kepada perlakuan jenayah ialah rumah kurang mempunyai ciri-ciri keselamatan dengan mencatatkan sebanyak 87.7 peratus responden yang menanda YA. Secara umumnya, ciri-ciri keselamatan rumah di kawasan ini seperti mempunyai pagar sekeliling rumah dan memasang gril pada pintu dan tingkat kerana penyediaan ciri-ciri keselamatan tersebut tidak memerlukan kos yang tinggi disebabkan penghuni kawasan ini terdiri daripada golongan berpendapatan rendah dan sederhana.

Sikap cuai penghuni terhadap aspek keselamatan rumah juga merupakan faktor kelima yang mendorong kepada perlakuan jenayah dengan mencatatkan sebanyak 86.3 peratus responden yang menanda YA. Kecuaian penghuni seperti tidak tutup dan kunci pintu rumah terutama ketika hendak meninggalkan rumah boleh memberi peluang kepada perlakuan jenayah untuk melakukan jenayah.

Faktor seterusnya ialah rondaan polis kurang kerap juga telah mendorong kepada perlakuan jenayah dengan mencatatkan sebanyak 82.1 peratus responden yang menanda YA. Kawasan perumahan Seksyen PJS 2 mempunyai rondaan oleh pihak polis namun, hanya kadang-kadang sahaja dan kawasan yang dironda juga tidak menyeluruh iaitu hanya kawasan perumahan yang baru menjadi mangsa penjenayah pecah rumah sahaja dironda.

Kecanggihan sains dan teknologi merupakan faktor ketujuh yang mendorong kepada perlakuan jenayah pecah rumah di kawasan ini dengan mencatatkan sebanyak 79.3 peratus responden yang menanda YA. Masalah jenayah ini semakin sukar dibendung kesan daripada kemajuan dalam sains dan teknologi. Seterusnya, kepadatan penduduk merupakan faktor kelapan yang mendorong kepada perlakuan jenayah pecah rumah di kawasan ini dengan mencatatkan sebanyak 75.6 peratus responden yang menanda YA.

Faktor terakhir yang mendorong kepada perlakuan jenayah pecah rumah di kawasan ini ialah tiada aktiviti rondaan oleh Rukun Tetangga dengan mencatatkan sebanyak 70.9 peratus responden menanda YA. Kebanyakan pintu masuk dan keluar ke kawasan perumahan tidak dijaga dan dikawal oleh Rukun Tetangga, Rela mahupun pengawal keselamatan yang bertindak untuk menjaga keselamatan kawasan kediaman.

Oleh demikian, kemudahan akses iaitu laluan keluar masuk yang mudah antara kawasan perumahan ini dengan Lebuhraya NPE merupakan faktor dominan yang mendorong kepada perlakuan jenayah pecah rumah. Jelas menunjukkan bahawa perlakuan jenayah pecah rumah di kawasan perumahan Seksyen PJS 2 mempunyai perkaitan dengan pengoperasian Lebuhraya NPE. 
Jadual 2. Pengetahuan responden terhadap faktor yang mendorong kepada perlakuan jenayah

\begin{tabular}{lcc}
\hline Kategori & Jumlah responden & Peratusan (\%) \\
\hline Kemudahan akses NPE & 314 & 88.0 \\
Kemudahan akses jalan perumahan & 325 & 91.0 \\
Kepadatan penduduk & 270 & 75.6 \\
Masalah sosial & 318 & 89.1 \\
Rondaan polis kurang kerap & 293 & 82.1 \\
Tiada aktiviti rondaan rukun tetangga & 253 & 70.9 \\
Kecanggihan sains dan teknologi & 283 & 79.3 \\
Kecuaian penghumi & 308 & 86.3 \\
Rumah kurang ciri keselamatan & 313 & 87.7 \\
\hline
\end{tabular}

Impak masalah pecah rumah dari aspek keselamatan kediaman dan hartabenda

Jadual 3 menunjukkan impak masalah pecah rumah dari aspek keselamatan kediaman dan hartabenda yang dialami oleh responden. Soalan soal selidik bagi bahagian ini adalah melibatkan pilihan jawapan Sangat Tidak Setuju, Tidak Setuju, Setuju dan Sangat Setuju. Berdasarkan jadual tersebut, impak tertinggi dialami oleh responden ialah hartabenda pemilik rumah tidak selamat dengan mencatatkan sebanyak 23.2 peratus responden Setuju dan 58.8 peratus responden Sangat Setuju dengan kenyataan tersebut.

Impak kedua tertinggi ialah 'risau jika hendak meninggalkan rumah terutama untuk tempoh masa yang lama' dengan mencatatkan sebanyak 23.5 peratus responden Setuju dan 52.1 peratus responden Sangat Setuju dengan kenyataan. Kebimbangan tersebut menjurus kepada rasa takut penghuni terhadap jenayah. Impak seterusnya ialah kenyataan 'selalu berasa tidak selamat ketika bersendirian di rumah' mencatatkan sebanyak 23.0 peratus responden Setuju dan 51.3 peratus responden Sangat Setuju. Impak terakhir ialah kenyataan 'berasa curiga melihat kelibat orang luar yang tidak dikenali' dengan mencatatkan sebanyak 23.2 peratus responden Setuju dan 41.7 peratus responden Sangat Bersetuju.

Oleh demikian, persepsi responden tentang impak masalah pecah rumah yang dominan ialah hartabenda tidak selamat dan diikuti oleh risau jika hendak meninggalkan rumah. Seterusnya, selalu berasa tidak selamat tinggal ketika bersendirian di rumah dan curiga melihat kelibat orang tidak dikenali merupakan persepsi responden tentang impak masalah pecah rumah. Jelas menunjukkan bahawa masalah pecah rumah boleh mempengaruhi psikologi seseorang. Mesej berkaitan jenayah pecah rumah yang diperolehi daripada jiran tetangga, saluran media dan petunjuk yang diterima daripada ruang atau persekitaran kediaman membuatkan penghuni tersebut berasa kadar jenayah meningkat dan kekal sama di kawasan kediaman ini, walaupun kadar jenayah pecah rumah mengalami penurunan sejak beberapa tahun kebelakangan ini. Akhirnya, ia menyebabkan wujud kebimbangan dan ketakutan terhadap jenayah di kalangan penghuni.

Jadual 3. Persepsi responden tentang impak masalah pecah rumah dari aspek keselamatan

\begin{tabular}{lcccc}
\hline Kategori & Sangat tidak setuju & \multicolumn{2}{c}{ Tidak setuju } & Setuju Sangat setuju \\
\hline Hartabenda pemilik rumah tidak selamat & 26 & 38 & 83 & 210 \\
& $7.3 \%$ & $10.6 \%$ & $23.2 \%$ & $58.8 \%$ \\
Risau jika hendak meninggalkan rumah & 37 & 50 & 84 & 186 \\
& $10.4 \%$ & $14.0 \%$ & $23.5 \%$ & $52.1 \%$ \\
Selalu berasa tidak selamat tinggal di rumah & 37 & 55 & 82 & 183 \\
& $10.4 \%$ & $15.4 \%$ & $23.0 \%$ & $51.3 \%$ \\
Curiga melihat kelibat orang tidak dikenali & 45 & 80 & 83 & 149 \\
& $12.6 \%$ & $22.4 \%$ & $23.2 \%$ & $41.7 \%$ \\
\hline
\end{tabular}


Namun, impaknya terhadap aspek keselamatan kediaman dan hartabenda yang dialami oleh responden adalah berbeza antara setiap responden kerana ia dipengaruhi oleh ciri demografi seseorang, salah satu contohnya ialah jantina. Analisis ujian chi-kuasa dua $\left(\mathrm{x}^{2}\right)$ dijalankan untuk melihat sama ada wujud perbezaan yang signifikan dari segi persepsi responden mengenai selalu berasa tidak selamat ketika di rumah antara lelaki dengan perempuan. Hasil ujian chi-kuasa dua mendapati terdapat perbezaan signifikan persepsi responden mengenai selalu berasa tidak selamat ketika di rumah antara lelaki dengan perempuan pada aras $\mathrm{p}<0.05(\mathrm{p}=0.000)$ dengan nilai $\mathrm{x}^{2}=37.012^{\mathrm{a}}$. Responden perempuan selalu berasa tidak selamat ketika di rumah melebihi responden lelaki iaitu masing-masing sebanyak 37.5 peratus dan 36.6 peratus. Keadaan tersebut mungkin disebabkan oleh kaum perempuan biasanya lebih dominan dengan sikap penakut dan curiga berbanding dengan kaum lelaki.

\section{Kesimpulan}

Hasil analisis trend jenayah pecah rumah di Seksyen PJS 2 antara tahun 2005 hingga 2017 menunjukkan pola penurunan. Penurunan tersebut mungkin disebabkan oleh keberkesanan tindakan pencegahan jenayah yang dilaksanakan oleh pihak polis dan Pihak Berkuasa Tempatan melalui pelbagai inisiatif serta usaha adaptasi yang dilakukan oleh penghuni itu sendiri bagi mengelakkan rumah mereka mudah di pecah masuk dan menjadi sasaran mangsa penjenayah. Kemudahan akses Lebuhraya NPE dan jalan perumahan, kepadatan penduduk, masalah sosial, kawalan keselamatan dan kecanggihan sains dan teknologi merupakan faktor pendorong kepada perlakuan jenayah pecah rumah. Sementara perasaan bimbang, takut dan tidak selamat terhadap jenayah pecah rumah adalah masih tinggi di kalangan penduduk tempatan walaupun, statistik jenayah di kawasan perumahan ini menunjukan kadar penurunan.

Penemuan kajian ini diharap dapat memberi kesedaran kepada penduduk setempat agar dapat mengurangkan perasaan tidak selamat dan kebimbangan terhadap masalah ini. Kadar jenayah pecah rumah di kawasan perumahan ini mampu dikurangkan lagi sekiranya mendapat kerjasama yang baik diantara pelbagai pihak sama ada agensi kerajaan, pihak swasta, NGO dan penduduk. Oleh itu, semua pihak perlulah berganding bahu dalam mengatasi masalah pecah rumah ini agar menjelang era Transformasi Negara 2050 kawasan perumahan ini menjadi kawasan yang selamat untuk didiami.

\section{Rujukan}

Aldrin, A. (1999). Crime landscape: The relationship of victimisation and fear of crime with residents' territorial functioning in high and low crime rate Estate in Sheffield. (Thesis Ph.D). University of Sheffield, U.K.

Aslie, M.R. (1990). Jenayah di Malaysia. Kuala Lumpur: AMK Interaksi Sdn. Bhd.

Blakely, E.J., \& Snyder, M.G. (1999). Fortress America-Gated communities in the United States. USA: Brookings Institution Press.

Brearley, H.C. (1932). Homicide in the United States. Chapel Hill, North Carolina: University of North Carolina Press.

Burt, C. (1925). The young delinquent. London: Appleton.

Cheng, Z., \& Smyth, R. (2015). Crime victimization, neighborhood safety and happiness in China. Elsevier Economic Modelling, 51, pp 424-435. 
Cozens, P.M. (2002). Sustainable urban development and crime prevention through environmental design the British city. Towards an effective urban environmentalism for the 21st Century. Cities, 19(2), 129-137.

Dewan Bahasa dan Pustaka. (2019). Kamus dewan edisi keempat. Retrieved from dictionary: http://prpm.dbp.gov.my/cari1?keyword=jenayah+pecah+rumah

Eck, J., \& Weisburd, D.L. (2015). Crime places in crime theory. Crime Prevention Studies, 4, 1-33.

Ekblom, P. (1995). Less Crime, by Design. The ANNALS of The American Academy of Political and Social Science, 539, 114-129.

Farrall, S., Gray, E., \& Jackson, J. (2007). Theorising the fear of crime: the cultural and social significance of insecurities about crime. Experience and Expression in the Fear of Crime, Working Paper No. 5.

Fink, G. (1969). Einsbruchstatort vornehmlich an einfallstrassen? Kriminalistik, 23, 358-360.

Hamersma, M., Tillema, T., Sussman, J., \& Art, J. (2014). Residential satisfaction close to highways: The impact of accessibility, nuisance and highway adjustment projects. Transportation Research Part A: Policy and Practice, 59, 106-121.

Harries, K.D. (1968). The geography of American Crime 1968. The Journal of Geography, 70, 204-213.

Hennessy, J.J., \& Pallone, N.J. (1992). Criminal behavior: A process psychology analysis. New Brunswick, NJ: Transaction Publishers.

Howard, M.R. (1999). Crime prevention through environmental design: an investigation of the effect of modular lotting on property crime. Landscape Architecture. Canada: The University of Guelph.

Jabatan Perangkaan Malaysia. (2018). Statistik Jenayah Indeks Malaysia 2017. Retrieved from https://www.dosm.gov.my/v1/

Jeffery, C.R. (1990). Criminology: An interdisciplinary approach. Englewood Cliffs, NJ: Prentice-Hall.

Jensen, J., \& Anderson, J. (2004). Crime prevention through environmental design criminology, 420-Term Paper.

Khan, A. (2015). Kejadian jenayah-Adakah anda peduli? Star Media Group Berhad. Retrieved from https://www.mstar.com.my/klik/2015/07/06/pemandu-5

Lembaga Lebuhraya Malaysia. (2018). Laporan Tahunan Lembaga Lebuhraya Malaysia Lembaga 2018. Retrieved from http://www.llm.gov.my/publication/yearbook

Lembaga Lebuhraya Malaysia. (2011). Laporan Tahunan Lembaga Lebuhraya Malaysia Lembaga 2011. Retrieved from http://www.llm.gov.my/publication/yearbook

Lembaga Lebuhraya Malaysia. (2008). Laporan Tahunan Lembaga Lebuhraya Malaysia 2008. Retrieved from http://www.llm.gov.my/publication/yearbook

Majlis Bandaraya Petaling Jaya. (2017). Latar belakang Petaling Jaya. Retrieved from http://www.mbpj.gov.my/en

Malaysia. (2016). Rancangan Malaysia Kesebelas 2016-2020. Malaysia: Kuala Lumpur.

Nasar, J.L., \& Jones, K.M. (1997). Landscapes of Fear and Stress. Environment and Behavior, 29(3), 291-323.

Kanyo, N-I, Nor, N.M., Rainis, R., Rahman, A.T.A., \& Jubit, N. (2015). Jenayah dan agenda pembangunan di Malaysia: Satu tinjauan. Geografia-Malaysian Journal of Society and Space, 11(1), 124-134.

PDRM. (2017). Laporan Statistik Jenayah di Seksyen Petaling Jaya Selatan 2 bagi Tahun 2005 sehingga 2017. Petaling Jaya, Polis Diraja Malaysia (PDRM).

Reckless, W.C. (1933). Vice in Chicago. Chicago: University of Chicago Press.

Schmid, C.B. (1960a). Urban Crime Areas, Part I, American Sociological Review, 25, 527543. 
Schmid, C.B. (1960b). Urban Crime Areas, Part II, American Sociological Review, 25, 655678.

Shannon, L.W. (1954). The spatial distribution of criminal offenses by states. Journal of Criminal Law, Criminology and Police Science, 45, 264-273.

Shaw, C.R., \& McKay, H.D. (1969). Juvenile Delinquency and Urban Areas (Rev. ed.). Chicago: University of Chicago Press.

Sidhu, A.S. (2005). The rise of crime in Malaysia: An academic and statistical analysis. Journal of the Kuala Lumpur Royal Malaysia Police College, 4, 1-28.

Tabrizi, L.R., \& Madanipour, A. (2006). Crime and the city: Domestic burglary and the built environment in Tehran. Habitat International, 10, 932-944.

Thomas, A.R. (1976). Crime prevention and the displacement phenomenon. Crime \& Delinquency, 22, 166-177.

Voss, H.L., \& Petersen, D.M. (1971). Ecology, Crime and Delinquency. New York, NY: Appleton.

Wolfgang, M. E. (1966). Patterns in Criminal Homicide. New York, NY: John Wiley \& Sons, Inc., Science Editions.

Yuen, B. (2004). Safety and dwelling in Singapore. Cities, 21(1), 19-28.

Zinalibdin, N., \& Lyndon, N. (2016). Makna rasa selamat komuniti Malaysia dalam Program Skim Rondaan Sukarela: Kajian kes KRT Taman Putera Jaya, Kota Kinabalu, Sabah, Malaysia. Geografia-Malaysian Journal of Society and Space, 12(5), 22-32. 